\title{
A HIDDEN CHALLENGE FOR FOSTERING INNOVATION: SELECTION OF IP VALUATION METHODS
}

\author{
DOI: 10.17261/Pressacademia.2018.949 \\ RJBM- V.5-ISS.3-2018(8)-p.251-268
}

\section{Aysun Beyazkilic Koc ${ }^{1}$, Nihan Yildirim²}

1/TUNOVA Technology Transfer Office, Istanbul Technical University, Istanbul, Turkey. aysun.koc@itunovatto.com.tr, ORCID: 0000-0002-5409-3287

${ }^{2}$ Istanbul Technical University, Istanbul, Turkey.

yildirimni@itu.edu.tr, ORCID: 0000-0002-6279-3849

Date Received: August 14, 2018

Date Accepted: September 28, 2018

To cite this document

Koc, A. B., Yildirim, N. (2018). A hidden challenge for fostering innovation: selection of IP valuation methods. Research Journal of Business Management (RJBM), V.5(3), p.251-268.

Permemant link to this document: $\mathrm{http}: / /$ doi.org/10.17261/Pressacademia.2018.949

Copyright: Published by PressAcademia and limited licenced re-use rights only.

\begin{abstract}
Purpose- There exist a large variety of sources on the definition or application process of the IP Valuation methods in literature, but there is still room for research for applications, related cases and preference criteria of each method as the theoretical and practical publications are very limited. Before starting IP valuation process there are some fundamental prerequisite steps such as setting the purpose of valuation, acquiring deep knowledge about the IP technology being valued, definition of the type of the process of patent application, defining TRL of IP and identifying the available data. To fulfil the gap of knowledge, the main aim of this study is to provide a case study for developing country context by exploring the current practices of patent valuation methods and determining the applicability, usefulness, challenges, necessities and advantages of IP valuation methods in IP ecosystems of technology.

Methodology- Within a qualitative research methodology which utilized the experiences of the IP valuation experts and professionals in technology transfer ecosystem in Turkey, Europe and USA, data were collected through structured in-depth interviews and Delphi Survey about level of expert knowledge, level of usage for different quantitative IP valuation methods, the purpose of using different IP valuation methods, challenges or benefits of applying the methods in patent valuation.

Findings- Findings revealed that replacement cost, reproduction cost, sales comparison, DCF, the 25 percent rule, comparable profit margin and RFR methods are widely preferred and known IP valuation methods which are priorly expressed by the respondent experts of this study. Advanced valuation methods are much rarely known and used when compared to previously stated methods. In order to make effective and well-supported estimates of an IP value, more than one valuation method which can be selected according to the objectives and different situations and qualitative parameters should be considered because of their indirect effect to the valuation.

Conclusion- The findings of this study show the whole necessities/inputs to apply valuation method in line with the literature. When an IP is valued, qualitative parameters should be considered because of their indirect affect to the valuation. In order to make effective and wellsupported estimates of an IP value, more than one valuation method which can be selected according to the objectives and different situations and qualitative parameters should be considered because of their indirect effect to the valuation. This study is expected to help valuers that are in need of choosing most suitable valuation method for their IPs.
\end{abstract}

Keywords: Intellectual property, IP valuation, IP valuation methods, Delphi Method. JEL Codes: M10, O32, O34

\section{INTRODUCTION}

In an era which the sustainable competitiveness resides in successful implementation of technology diffusion and innovativeness, IP management and utilization of intellectual assets occurs as a challenge especially for organizations which strategize on differentiation through innovation. Success of technology protection and transfer of protected technology (which can be categorized as one of the main pillars of technology management process (Çetindamar, Phaal and Probert, 2010) requires patenting processes which are systemicly structured to provide economic and operational feasibility.

From the resource based view, IP protection is a strategic tool that enhances intellectual assets for the aim of maximized return of investments in $R \& D$. 
In this context, rational selection of intellectual property valuation methods, and in particular, patent valuation methods occurs as a critical business activity that adds value to organizations through providing cost effective technology protection and technology licensing opportunity. Intellectual property valuation is a major topic that have significant effect on technology development, innovativeness, $R \& D$, and manufacture based R\&D, return on investment/income and completion performance in technology development and innovation ecosystems. Therefore, the awareness about IP and IP valuation is essential for growth and innovativeness of companies, universities, public institutions and government agencies. According to Triple Helix technology development ecosystem approach, The Universities have a pioneering role for value adding R\&D activities. Therefore, R\&D management and intellectual property management are key roles of University Technology Transfer Offices. The activities of University Technology Transfer Offices (TTOs) in Turkey and all over the world underlined and proved the importance of the commercialization of IPRs in deployment and diffusion of technologies and innovations. The intellectual properties may be valued for various purposes such as making strategic decisions, merger and acquisition processes of companies including joint venture, negotiations and transactions to sell or license intellectual properties, court proceedings, taxation purposes etc. As can be seen from the Science and Technology Indicators (STI) statistics, in recent decades there is a significantly increasing trend in the number of global patent applications and registrations/grants. This increase in patenting and IP awareness also had been evident for Turkey where perceptions and initiatives regarding the registration of technology, invention, intellectual property rights gained momentum. Therefore, intellectual property issues were addressed within the scope of several state policies for Universities and Industries to support technology oriented growth. To know the value of an owned IP portfolio is strategically important for owners and inventors whether they are legal entities or natural persons. At this point, the purpose of the valuation and the preference of the appropriate valuation method gains importance because of their impact on effectiveness of applications and business results.

According to Corporate Tax Law numbered $5520,50 \%$ of the profits of companies and universities that were obtained from the activities of the registered Patent and Utility Model. For Technopark firms, it is necessary to obtain a patent or equivalent certificate to exempt from corporate taxation of income from the sale of their intangible assets (Technology Development Zones Law numbered 4691). On the other hand, university Rankings for Innovativeness and Entrepreneurship performances are published every year in Turkey and in all over the World such as "Times Higher Education Ranking" and Ranking of the Entrepreneurial and Innovative University Index organized by Council of Higher Education. This index also forces universities to focus on getting patents through TTOs for improving their ranking. In this context, again IP Valuation becomes significantly important for utilizing the limited financial resources in the best way by choosing the best method.

Global trends that creates a need for research on the appropriateness of IP valuation methods can be summarized as the big share of company values became to be intangible, IP registration is growing rapidly as knowledge economy accelerates. Hence IP Laws are changing and litigation continues to grow. There exist a large variety of sources on the definition or application process of the IP Valuation methods in literature, but there is still room for research for applications, related cases and preference criteria of each method as the theoretical and practical publications are very limited. Application of some methods requires high level expertise and know how about IP valuation. Before starting IP valuation process there are some fundamental prerequisite steps such as setting the purpose of valuation, acquiring deep knowledge about the IP technology being valued, definition of the type of the process of patent application, defining TRL of IP, identifying the available data and etc. All fundamentals affect the preference for the valuation methods. Even if the value setter meets almost all requirements of a valuation method, they may still not be able to use the method effectively because of its difficulties/challenges. As well, the opposite condition can also may apply. Moreover, in literature, there are limited studies about patent valuation practices in developing country contexts. Similarly, limited number of studies are available for the patent valuation in Turkey. Besides this, IP valuation experience and knowledge of experts are insufficient in Turkey. All types of quantitative methods were not explored by comparing all methods relatively with each other and also the experience and competency of experts in all of the IP valuation methods were not searched as a whole. In general, the comparisons of IP valuation methods were made and main evaluation approaches were exemplified in categories of cost approach, market approach, income approach and sometime advanced method. Therefore, a study based on experiences and knowledge of experts is essential because of the fact that the preference of the appropriate valuation method is highly important for all actors in technology transfer ecosystems.

The main aim of this study is to explore the current practices of patent valuation methods and determine their applicability and preferences of valuers in different contexts and in various cases of IP ecosystems of technology transfer based on the experiences and knowledge of experts in this field. For this aim, within a qualitative research methodology which utilized the experiences of the IP valuation experts and professionals in technology transfer ecosystem in Turkey and Europe. Data were collected through structured in-depth interviews and Delphi Survey about level of expert knowledge, level of usage for different quantitative IP valuation methods, the purpose of using different IP valuation methods, challenges or benefits of applying the methods in patent valuation. In the study, usage and perceptions about the usability/appropriateness of these methods are explored by qualitative analysis. 
This article consists of three parts:

(1) Literature review on the definitions of intellectual property rights, viewpoints on IPR in Turkey and the World, the definitions and discussions of the value, valuation and IP valuation methods;

(2) methodology section where the definitions and discussions of the research methods and techniques used in the study are explained;

(3) the process and findings of the Delphi survey and interviews,

(4) elaboration and summary of findings, discussions, conclusions, limitations of the study and the recommendations for future research.

\section{LITERATURE REVIEW}

Strategic management of technology and innovation approach includes activities of identification, selection, acquisition, protection and expoitation of technology in a competitiveness oriented way. Among these activities, technology protection processes plays the major role in providing maximized returns of R\&D investments (Figure 1: Gregory, 1995).

Figure 1: Technology Management Activities

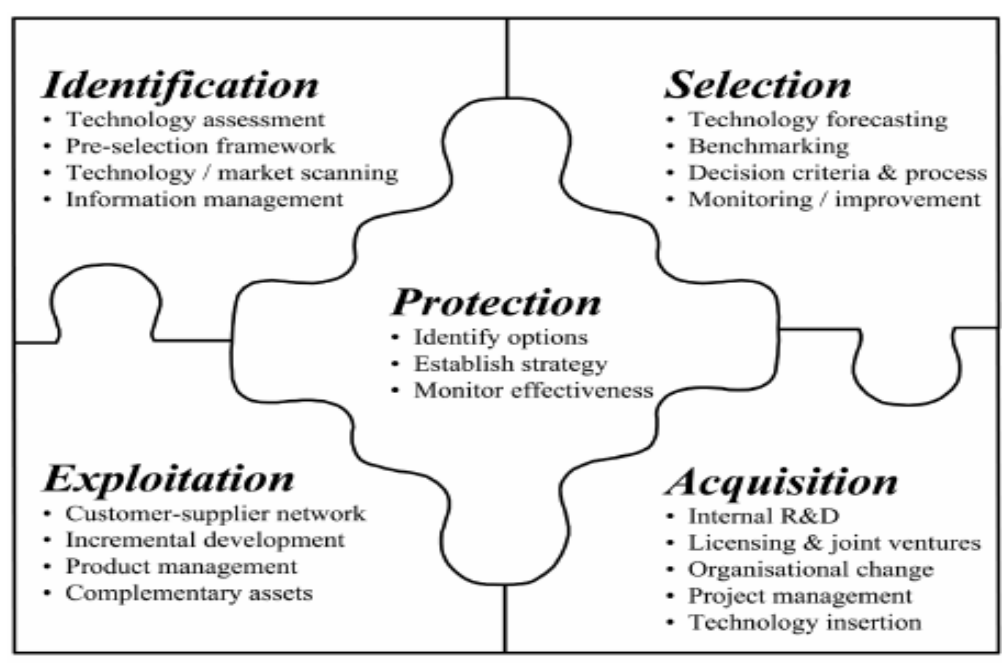

Source: Gregory (1995)

In their book, Çetindamar, Phaal and Probert (2010) also listed technology activities in a similar way but adding "Learning" activity to Technology Management framework. This framework is enhanced by supporting activities of Strategic Management, knowledge management, innovation management and project management. All these Technology Management activities and supporting activities determines the technology management capability that leads to competitive advantage and finally to firm performance (Unsal and Çetindamar, 2015).

In an era which the sustainable competitiveness resides in successful implementation of technology diffusion and innovativeness, IP management and utilization of intellectual assets occurs as a challenge especially for organizations which strategize on differentiation through innovation.

As well, from the resource based view, IP protection is a strategic tool for enhancing intellectual assets with the aim of maximized return of investments in R\&D. Success of technology protection and transfer of protected technology (which can be categorized as one of the main pillars of technology management process (Çetindamar, Phaal and Probert, 2010) requires Intellectual Property (IP) Protection processes which are systematically structured to provide economic and operational feasibility. Intellectual property rights allow owners of patents, trademarks or copyright to benefit from their IP right in a creation. The importance of intellectual property was first acknowledged in the Paris Convention for the Protection of Industrial Property (1883) and the Berne Convention for the Protection of Literary and Artistic Works (1886). These two treaties are administered by the World Intellectual Property Organization (WIPO). 


\subsection{IP Value and Valuation}

The subject of a valuation can be a single right, or a portfolio of complementary IP rights and other intangible items. Intellectual property rights that are frequently the subject of transactions and valuation reports are those associated with brands, technology and artistic works (RICS, 2015). The value is the current price of the economic benefit to be obtained in the future depending on the use of an asset. In other words, value is the expression of the future benefits of having an asset in a single payment. The valuation is the process of determining the monetary value of an asset. The valuation was first started to be use for real estate. Over time, it has been applied for machine equipment, precious stones, art works and finally intangible assets (Sozer, 2008). Valuation is the process of identifying and measuring benefit and risk from an intangible asset. (WIPO, 2012). Economic benefits of an IP can be classified as direct or indirect. It should be direct economic benefit that patent rights can create a direct cash flow stream for the owner that could not be earned without this IP. Saving money depend on reducing cost or eliminating negative costs and indirectly help to generate cash flow are defined as indirect economic benefits. Patent have also noneconomic value such as the prestige, personal achievement and feeling of accomplishment. The noneconomic value of patents may show why so many patents are applied and sustained each year (Murphy et al., 2012). The useful economic life of a patent might be shorter than its legal life and cannot exceed the remaining term of protection. Patent specifications become publicly available, so, once the period of legal protection has expired, the invention can be used by other parties and surplus earnings will be eroded (RICS, 2015). In order to value an IP, it must first be an identifiable entity (technology), a legal title of the entity (being a proprietor and transferable), and making revenue on its own (Taplin, 2004, p.8). When a patent value is expressed, it should be indicated when the valuation is made. Because the value of an entity changes over time, depending on the increase or decrease of the benefit that it will bring in the future. Hence, every value expresses a meaning for a certain time (today and future). If a patent has not been used today, which makes it profitable in the past, the value is zero. At this point it is important to note that although they are sometimes equal and can be used interchangeably, cost, price and value are related but different concepts (Smith \& Parr, 2000, p.152). Reilly (1999) refers that the price, which always refers to the past, requires a certain market and operation. In order for price to be an indicator of value, at least five factors need to be considered:

- Market conditions (such as whether the price reflects the price at the time of the transaction, whether the price reflects the value at the time the valuation is made, etc.)

- Market place (where the price of the transaction is realized when there is an effective market, whether the buyer is the buyer or the seller, whether there is a competitive price offer, how many days / months /

- $\quad$ Buyers 'and sellers' motive (whether or not each party is willing to act, etc.)

- Method of payment (such as whether the payment is made in cash or otherwise, the payment is made during or after the transaction, etc.)

- The elements of the transaction (whether the transaction is for only patent only or for other assets with the patent, whether the contracts other than the transaction, such as warranty, development, use are signed).

Regarding the future use, the value of the patent differs by purpose of the valuation. There are many types of patent values that emerged in accordance with different valuation purposes (value types are generally classified as Fair Market Value, Fair Value, Market Value, Historical Value, Acquisition Value, Use Value, Investment Value, Owner Value, Insurable Value, Assurance Value, Ad Valorem Tax Value) (Sozer, 2008).

There are many reasons for valuing intellectual properties:

- making strategic decisions, getting prepared for merger and acquisitions, joint ventures or bankruptcy,

- negotiating on the transactions to sell or license intellectual properties, court proceedings or alternative dispute resolution mechanisms,

- $\quad$ making decisions for investments of venture capital,

- $\quad$ accounting and taxation purposes and

- $\quad$ country selection for the registration of intellectual property (Speier \& Gupta, 2015).

In Table 1, commonly mentioned evaluation purposes in the literature are presented. Also the application possibilities in Turkey are asked to respondents in in-depth interviews and they are listed in accordance with valuation purposes. 
Table 1: Valuation Purposes (Sozer, 2008.; EC,2013)

\begin{tabular}{l|ll}
\hline \hline \multicolumn{2}{l}{ Valuation Purposes } & $\begin{array}{l}\text { Applicable } \\
\text { Turkey? }\end{array}$ \\
\hline & Transaction-Mergers and Acquisitions & Not found. \\
& Licensing (technology transfer) & Yes \\
& Financial Reporting (presentation of Intangible Asset in financial statements) & Partially \\
& Financing (patents as collateral for bank loan, Sale and Leaseback as financial funding) & No \\
& Insurance applications (patent insurance against infringements as risk management) & No \\
Legal (Infringements trail courts) & Yes. \\
Tax purposes & Yes (Since 2015) \\
Patent Donations (Tax deduction by donations to NPOs) & No \\
Transfer pricing (For multinational enterprises and tax administrations) & Yes (Since 2007) \\
& Internal management decisions & Yes \\
\hline
\end{tabular}

As part of the strategy to support research, development and innovation activities in Turkey, patent valuation is gaining momentum. Although it is not as fast as in other countries, the state opens the way by arranging various laws. According to current the General Communiqué on the Amendment of the Corporate Tax (Official Gazette, 2015); the scope of earnings and revenues obtained from IPR has been updated. With this revision; tax exception, regulation of patent valuation report, valuation and related processes are enacted. A tax exception of up to $50 \%$ of the price stated in the valuation report has been introduced. This development is expected to increase the number of patent valuation cases in Turkey.

Patent valuation is an interdisciplinary study which must include economics, law, finance, accounting and investment decision making expertise. For this reason, it is difficult to determine where to begin valuation. Since valuation needs (or perspectives) vary for individuals and institutions, there is no generally accepted valuation process in the literature. Hadzima (2013) mentions that coming up with IP valuation is complicated. Companies must follow three steps to valuate an IP. The quality of the invention, well-constructed patent and way to extract value from the patent. Several valuation process suggestions are suggested in literature, some has distinctive perspectives, like Chiu and Chen (2007). They established a patent valuation system from the perspective of licensor using AHP (Analytic Hierarchy Process) in order to determine the importance of patent valuation indicators. They conducted a case study on Taiwanese Company with a scoring system which utilizes below given hierarchy structure in Figure 2.

Figure 2: Patent Valuation Hierarchy Structure (Chiu \& Chen, 2007)

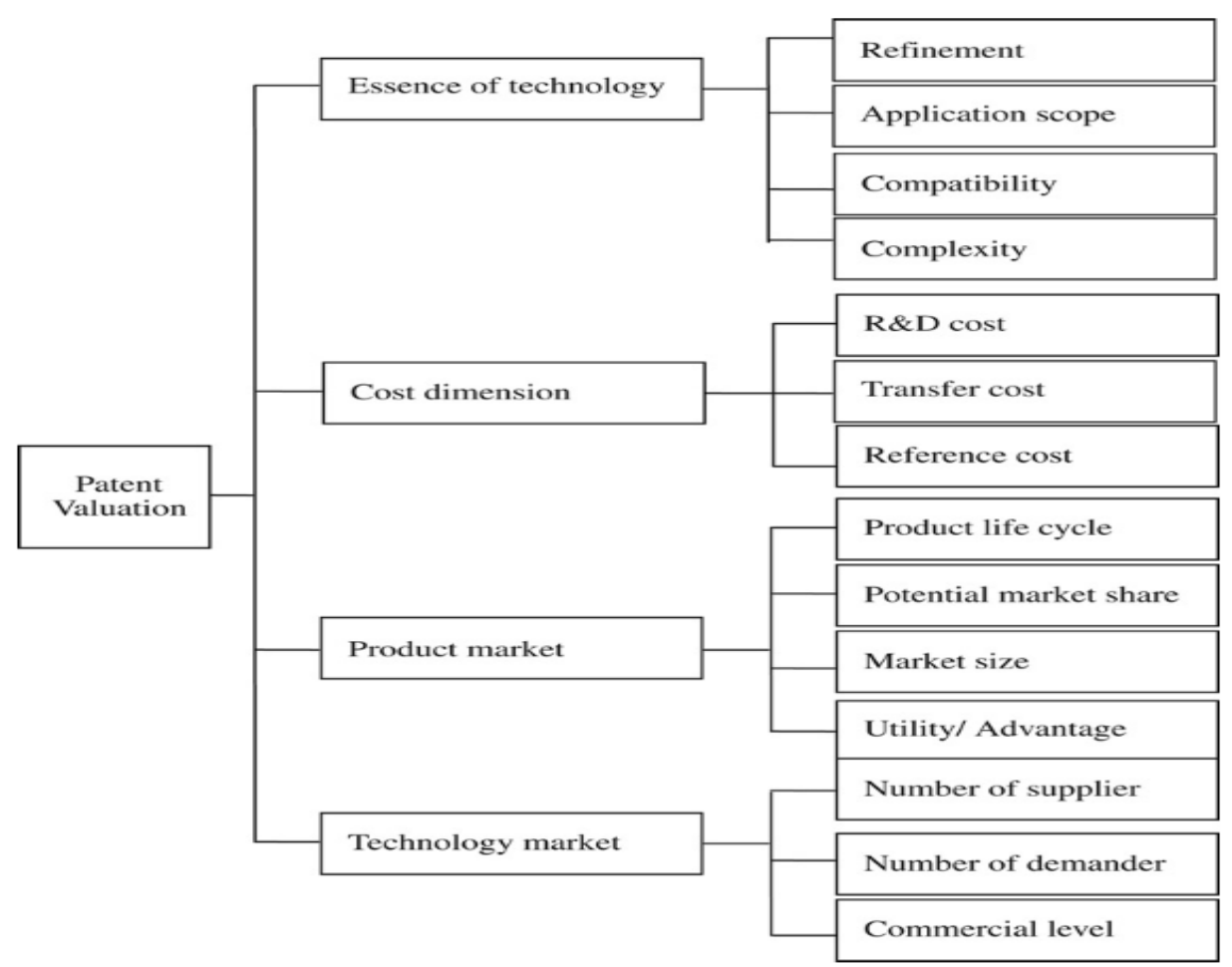


Flignor and Orozco (2006) suggest a game plan for valuation and build a valuation pyramid which is shown Figure 3 . They create a valuation context in their work that would cover the all segments (licensee, licensor, investor, management etc.) that might need valuation. The foundation level of the pyramid includes steps of purpose, description, premise and standard of IP valuation. "Why are you valuing the asset?", "What is the asset?", "How will the asset be used?" and "Who is the assumed buyer of the asset?" questions are answered. In the Profile phase, legal, business/strategic and financial characteristics of the assets are determined. Most of the difficult work and creative energy of valuation analysis occurs at this level. The extensive availability of data is important to IP valuation method selection. The final level of the valuation process is to express the important issue of how the valuation analysis solves a business problem or generates a recommendation to a specific business question. In summary, they offer an answer to the question of where and how to begin valuation.

Figure 3: Valuation Pyramid (Flignor \& Orozco, 2006)

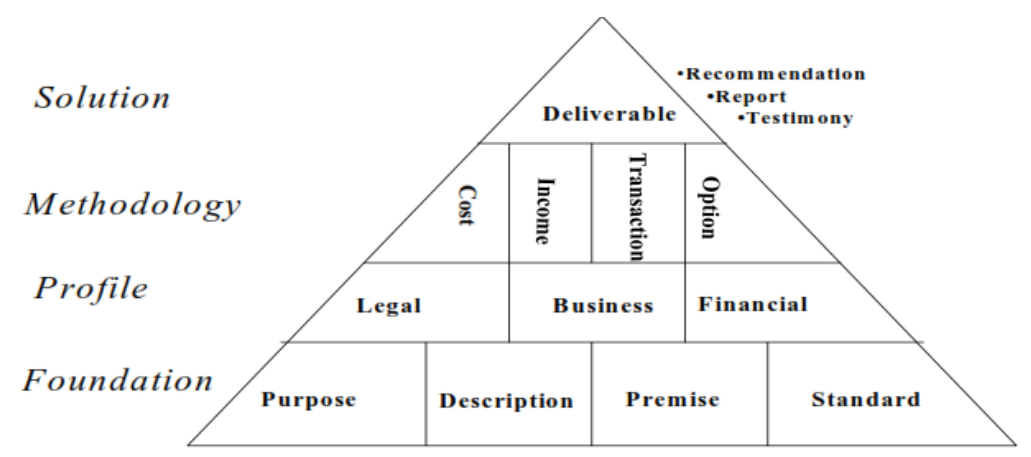

In literature there is a few research and publication that is directly involved in evaluation of IP Valuation Methods. In their inter-disciplinary study Chiu and Chen (2007) stated that economics, law, finance, accounting and investment decision making expertise is required for IP Valuation. They performed a case study on Taiwanese Company with a scoring system which includes cost dimension, essence of technology, product market, technology market. With pyramid, Flignor and Orozco (2006) seek answer for the asset being valued (purpose, description, financial, business, legal, methodology and solution). Cromley (2004) has as start point check validity of IP in a process with steps of context, data, team, infringement, remaining life, next best alternative, prior royalties, profit maximization. Themes and references about IP Valuation which are primarily utilized in this study are shown in Table 2.

Table 2: Highlights from Previous Literature and Themes on IP Valuation

\begin{tabular}{|l|l|l|}
\hline Theme & References & Context \\
\hline Patent valuation process & Chiu and Chen (2007) & Scoring system using AHP on Taiwanese Company \\
\hline Patent valuation process & Flignor and Orozco (2006) & $\begin{array}{l}\text { A game plan for valuation and build a valuation } \\
\text { pyramid }\end{array}$ \\
\hline Patent valuation process & Cromley (2004) & 20 steps to value American Patents \\
\hline
\end{tabular}

\subsection{IP Valuation Methods}

For business purposes, methods can be divided into two approach: quantitative and qualitative. Before any other aspects of the valuation process are analyzed is decided between a qualitative and a quantitative approach. Different valuation approaches are required if the target audience comprises prospective investors or internal management (Lagrost et al., 2010). The value of a patent or company is obtained from the advantage which it provides its owner (Smith \& Parr, 2005). At the earliest stages, the valuations based on generally qualitative information because of the very little quantitative information availability. Qualitative methods are mostly used for the purpose of the IP management and the business strategy through comparing, categorizing and ranking the IP of the firm. (Cohen, 2005). In order to measure the strength of the patent, rankings and scoring methodologies can be used as qualitative approaches. Although these methods do not give a conclusion about the patent's monetary value, they can valuate it with the accepted parameters of the patent's strength and future potential. When the technology is developed, more information, on both the technical and market aspects will become easily accessible and valuations will become increasingly quantitative (Stevens, 2016). The three-different traditional valuation approach provide to measure of this benefit. These three basic concepts are Income, Market and Cost methods (Goddar \& Moser, 2011, pp. 109-110). In addition to the traditional valuation methods, a few advanced valuation methods are used for value an IP. The reason why they are called advanced methods is that they contain more complex 
mathematical calculations than the NPV method. Risk Adjusted NPV Method, Probability Tree Analysis, Monte Carlo Method and Real Option Pricing Method are most known of advanced methods (Sozer, 2008). Selection of an appropriate method depends upon the circumstances surrounding the valuation, including the type of IP being valued, the purpose of valuation, the basis of valuation and most importantly the availability of information (Singh and Palival, 2014). Primary literature list for IP Valuation previous research is given below in Table 3:

Table 3: IP Valuation Methods by Approaches and References

\begin{tabular}{|c|c|c|}
\hline Approaches & Methods & References \\
\hline $\begin{array}{l}\text { Qualitative } \\
\text { Approaches }\end{array}$ & $\begin{array}{l}\text { Number of patents in a Technology field } \\
\text { Number of patent claims } \\
\text { Number of 3rd party objections of the patent } \\
\text { Number of citations } \\
\text { Geographical area covered by patent } \\
\text { Width of the related technical field } \\
\text { Infringement detection method } \\
\text { Patents legal life } \\
\text { Duration of patent application } \\
\text { Patent renewal fee }\end{array}$ & $\begin{array}{l}\text { Chiu and Chen 2007, Hamamcıoğlu and } \\
\text { Kahraman 2015, Speier and Gupta 2015, } \\
\text { Lanjouw and Schankerman 2003, van der } \\
\text { Drift 1989, Harhoff and Scherer et al. 2003, } \\
\text { Trajtenberg 1990, Putnam 1996, Griliches } \\
\text { 1998, Marr et al. 2003, Narin and Noma } \\
\text { (1987) }\end{array}$ \\
\hline $\begin{array}{l}\text { Quantitative } \\
\text { Approaches }\end{array}$ & $\begin{array}{l}\text { 1. Cost Methods } \\
\text { What would it cost to replace or reproduce the future } \\
\text { capability of an asset? } \\
\text { 2. Market Methods } \\
\text { Are there similar transactions in the market } \\
\text { to provide comparators? } \\
\text { 3. Income Methods } \\
\text { What additional profits/cash will the IP } \\
\text { generate in the future } \\
\text { 4. Advanced Methods }\end{array}$ & $\begin{array}{l}\text { Smith \& Parr 2005, Stevens 2016, Flignor and } \\
\text { Orozco (2006), Goddar \& Moser, 2011, Sozer } \\
\text { 2008, Speier \& Gupta, 2015, Murphy et al. } \\
\text { (2012), Pitkethly, 1997, Reilly (1998, Holt et } \\
\text { al.,2015, Anson et al.,2014, Parr (2016), } \\
\text { Ferguson (2016, Carte, 2005, Andriessen } \\
\text { (2004), Anson \& Suchy 2005, Razgaitıs, 2009, } \\
\text { Oriani \& Sereno, } 2011\end{array}$ \\
\hline
\end{tabular}

\subsection{Intellectual Rights in Turkey}

Legal arrangements regarding the industrial property in Turkey date back to the 1870s. 1871 dated " Eşya-i Ticariyeye Mahsus Alamet-i Farikalara Dair Nizamname " and 1879 "ihtira Beratı Kanunu " constitute the basis of legal protection in Turkey. With these arrangements, Turkey is among the first countries to provide protection for industrial property rights. In the first years of the Republic of Turkey, the IP protection was considered important. Also in 1925, Turkish state was represented in Paris Convention on the Establishment of an International Union for the Protection of Industrial Property. "Brand Law" (numbered 551 issued in 1965) and participation to "World Intellectual Property Organization (WIPO) Establishment Agreement" in 1976 were the important steps towards developing industrial property rights protection in Turkey. The establishment of the Turkish Patent Institute with the Decree Law No. 544 on June 24, 1994 has been a milestone in the field of industrial property rights. With the Industrial Property Law No. 6769 dated December 22, 2016, the name of the Corporation has been changed to "Turkish Patent and Trademark Authority" and its short name is "TURKPATENT". On 10 January 2017, according to the Industrial Property Law No. 6769, decree laws which are separately prepared for trademark, patent, design and geographical indications are collected under one law. With training and promotional activities, important studies have been carried out to raise awareness of the public. In this scope, as of the end of 2016, 100 TURKPATENT Information and Documentation Units have been established, including many universities and industry and trade chambers (TPE).

According to Cetin (2017), in the recent years, there has been a rapid rise in the field of technology, inventions and the registration of intellectual property rights in Turkey. Especially during the last 10 years, incentive regulations for $R \& D$ investments in Turkey have been made and great support has been given to researches of brands, patents, utility models which are an output of these investments. For this reason, the issue of intellectual property has been addressed within the scope of state policy and with an arrangement made in the Corporate Tax Law (numbered 5520) to support technologyoriented growth. $50 \%$ of the profits obtained from the activities of the Patent and Utility Model Documents issued by the Turkish Patent Institute has been exempted in 2014.

The amount to be applied for the exemption shall be determined by the valuation report prepared by the Ministry of Finance for the determination of the value of the invention in the event of transfer or sale, taking into consideration the value added (Cetin, 2017). Table 4 shows that the total number of The Number of Patent Application to TURKPATENT. 
Table 4: The Number of Patent Application to TURKPATENT (TURKPATENT)

\begin{tabular}{|c|c|c|c|c|c|c|c|c|c|}
\hline \multirow{2}{*}{ Year } & \multicolumn{4}{|l|}{ Domestic } & \multicolumn{4}{|l|}{ Foreign } & \multirow{2}{*}{ TOTAL } \\
\hline & TURKPATENT & PCT & EPC & Total & TURKPATENT & PCT & EPC & Total & \\
\hline 1995 & 170 & 0 & 0 & 170 & 1520 & 0 & 0 & 1520 & 1690 \\
\hline 1996 & 189 & 0 & 0 & 189 & 687 & 26 & 0 & 713 & 902 \\
\hline 1997 & 202 & 1 & 0 & 203 & 598 & 730 & 0 & 1328 & 1531 \\
\hline 1998 & 201 & 6 & 0 & 207 & 596 & 1680 & 0 & 2276 & 2483 \\
\hline 1999 & 265 & 11 & 0 & 276 & 524 & 2220 & 0 & 2744 & 3020 \\
\hline 2000 & 258 & 19 & 0 & 277 & 442 & 2714 & 0 & 3156 & 3433 \\
\hline 2001 & 298 & 39 & 0 & 337 & 119 & 2756 & 2 & 2877 & 3214 \\
\hline 2002 & 387 & 27 & 0 & 414 & 88 & 1335 & 37 & 1460 & 1874 \\
\hline 2003 & 454 & 35 & 1 & 490 & 43 & 305 & 314 & 662 & 1152 \\
\hline 2004 & 633 & 49 & 3 & 685 & 68 & 167 & 1342 & 1577 & 2262 \\
\hline 2005 & 895 & 33 & 7 & 935 & 75 & 143 & 2308 & 2526 & 3461 \\
\hline 2006 & 979 & 93 & 18 & 1090 & 71 & 89 & 3915 & 4075 & 5165 \\
\hline 2007 & 1747 & 60 & 31 & 1838 & 71 & 139 & 4141 & 4351 & 6189 \\
\hline 2008 & 2159 & 69 & 40 & 2268 & 68 & 107 & 4694 & 4869 & 7137 \\
\hline 2009 & 2473 & 74 & 41 & 2588 & 69 & 105 & 4479 & 4653 & 7241 \\
\hline 2010 & 3120 & 60 & 70 & 3250 & 77 & 100 & 4916 & 5093 & 8343 \\
\hline 2011 & 3962 & 43 & 82 & 4087 & 120 & 100 & 5934 & 6154 & 10241 \\
\hline 2012 & 4360 & 74 & 109 & 4543 & 78 & 154 & 6824 & 7056 & 11599 \\
\hline 2013 & 4345 & 54 & 129 & 4528 & 95 & 175 & 7257 & 7527 & 12055 \\
\hline 2014 & 4654 & 112 & 95 & 4861 & 149 & 183 & 7182 & 7514 & 12375 \\
\hline 2015 & 5302 & 50 & 160 & 5512 & 251 & 238 & 7957 & 8446 & 13958 \\
\hline 2016 & 6153 & 88 & 204 & 6445 & 407 & 211 & 9715 & 10333 & 16778 \\
\hline
\end{tabular}

As indicated in the Table 4, the number of patent application to TP and registrations given by TP to both domestic firms, organizations and individuals has increased rapidly in recent years. The domestic part indicates the data of applicants who are citizen of the Republic of Turkey or companies located in Turkey. As it is known, the applicant has either applied directly to TURKPATENT or has passed the national stage from the PCT application or has taken the European patent and has validated it in our institution. Foreign part shows that the data of applicants who are citizen of a foreign country or a company that is based in a foreign country. The number of domestic patent applications to TP increased roughly 5 times and the number of the domestic registered patent by TP increased 13,7 times compared to 10 years ago.

In Turkey, there is no established market structure or mechanism functioning on technology transfer to industry. The Ministry of Science, Industry and Technology announced on 28 July 20016 that a Stock Exchange of Intellectual Property will be established within the Istanbul Stock Exchange (MSI, 2016). In addition, there are 34 Technology Transfer Offices established in Turkey for the transfer of technological inventions to companies and generally located in the Universities and Universities' Technoparks. Technology Transfer Offices (TTO) were established with the aim of commercializing the knowledge and technology that are produced by the universities and obtaining economic/social/ cultural value as a result of this process. They also establish cooperation between the universities and private sector institutions and to produce the knowledge and technology that the industry needs and as a result of these collaborations, contribute to the transfer of information and technology between universities and industry and the development of concrete outputs. TUBITAK has been tasked with the support of Technology Transfer Offices with the decision of High Council of Science Technology (BTYK).

\section{DATA AND METHODOLOGY}

The aim of the study is to explore the current practices of patent valuation methods and to determine the applicability of these methods in different contexts and in various cases of IP ecosystems of technology transfer based on the experiences and knowledge of experts in this field.

The preference of the appropriate quantitative valuation method significantly affects the application process and achieved results. In this context, the main research questions of the study are designed as follows:

- What is the level of expert knowledge and level of usage for different patent valuation methods?

- Why and how are different valuation methods used? The aim of using different valuation method

- What are the advantages or difficulties of patent valuation methods? 
The motivation of this study is also inspired by the fact that I work as a technology transfer professional and expert in ITUNOVA Technology Transfer Office that is TTO of Istanbul Technical University. Intellectual property valuation is a critical part of my job. My colleagues and I know that IP valuation is a necessity at the right time for commercialization. It requires multidisciplinary studies and applying right strategies. During the valuation process, we deal with many uncertainties. I experienced that the different valuation technique gives different results. IP valuation method can be learned theoretically but its application requires a different kind of expertise. Before starting this research, I've consulted the General Manager of ITUNOVA Technology Transfer Office and we've discussed the need of a research regarding IP valuation especially for University based technologies. This is the motivation of this research for exploring IP valuation experts' opinions and experiences. For verifying the research, I conducted some structured in-depth interviews with IP valuation experts from Universities, TTOs, Patent Offices or Intellectual Capital Firms and national or international patent organizations at various meetings and conferences. As well, a two-round Delphi survey was made for gaining insights on the experts' perceptions about the IP valuation methods together with literature review.

\subsection{Data Collection}

To begin with the literature, we searched about the theoretical and regulative frameworks of intellectual property, patent valuation method and research methods. For primary data, we conducted Delphi survey, structured in-depth interviews, observations and self-history.

For verifying the research, we conducted some structured in-depth interviews with IP valuation experts from Universities, TTOs, Patent Offices or Intellectual Capital Firms and national or international patent organizations at various meetings and conferences. Pre-interviews were utilized in designing the finalized Delphi survey questionnaire and also the interviewees were asked to provide the information about potential participant experts for the survey. Based on interviewees' references, participants are invited to Delphi survey.

As well, a two-round Delphi survey was made for gaining more insights on the experts' perceptions about the IP valuation methods by taking the literature review and expert opinions into account. The history of Delphi Technique is based on the study concerning the use of expert opinion of Air Force-sponsored RAND Corporation in early 1950's. They had begun investigating the scientific use of expert opinion and published several studies that group judges were superior to individual judges. The Delphi study was applied here for the first time as part of a defense project with all its features (Dalkey \& Helmer, 1963, p.458). The Delphi approach, a quantitative research method, is the most appropriate method that can be used when expert opinions are sought, evidence is low or not significant. The advantage is that it exposes the experts as an individual (Okoli and Pawlovski, 2004). In general, the characteristics of the Delphi study are anonymity, repetition, controlled feedback and statistical group response (Landeta, 1999). Delphi method can be used for situation detection and estimation (Brancheau et al., 1996; Hayne \& Pollard, 2000). Since there are not too many experts on patent valuation in Turkey, it was necessary to reach the experts abroad. It was not possible to bring together all the target participants and make a focus group meeting or personal interview. This is particularly useful when there are only a limited number of experts in a field of interest (Culley, 2011). Therefore, in this study, Delphi survey method were chosen to gain more insight into the experts' perceptions about the IP valuation methods.

We discussed the aim of our research with some experts from EPO, Deutsches Patent und Markenamt and Technisches Informationszentrum Berlin at PATLIB2017 conference which was organized by EPO as a learning event that took place on May 2017. Patent Information Centres (PATLIB centres) in Europe attend this event regularly. The experts that were interviewed have given some opinions, advices and IP valuation expert recommendation for study planning process and said that they can contribute at the data gathering process. In this study, I also used my own knowledge as an expert contribution with my 5 years' career as a technology transfer professional. I know that IP valuation is a necessity at the right time for commercialization. The individuals who were invited to the survey have the following characteristics:

- $\quad$ Professionals working on Intellectual Property management and technology investment,

- Researchers studying on Intellectual Property, business valuation, IP valuation and evaluation,

- $\quad$ Experts from TTOs, Patent Offices, Intellectual Capital Firms, national/ international patent organizations.

In the first round, the Delphi survey was sent to totally 87 experts from Turkey, UK, USA, Germany, Hungary, Austria, Luxembourg and Holland. Experts who did not respond within 10 days of the posting were sent an e-mail reminding them. 15 experts from different countries out of the 87 , responded to the survey. The response rate is approximately $\% 17$. The Delphi surveys results were reviewed for their face validity. There were some irrelevant answers for two open ended questions showing that these questions were misunderstood by the respondent. Therefore, teleconference was made with the responder. In the second round of Delphi survey, the outputs of the first round responses as report were shared with all participant to receive their final consensus and opinion about the results. Totally 11 participants participated in second 
round. With two of them have made face to face interview with regard to all questions and answers. All of Delphi survey respondents generally confirmed the findings.

The reliability and validity of any research work should be considered in any research study. Reliability is the rate at which a procedure produces similar results under constant conditions under all conditions. In two or more panels which are given the same information, same results don't be obtained. Therefore, there is no evidence of the reliability of the Delphi method. It is unlikely that a few people will reach a wrong decision than one person. It can be said that Delphi method is based on the assumption of safety in numbers. The decisions are then strengthened by logical arguments that are challenged by the assumptions, thus helping to increase their validity. Besides, the participation of individuals who have knowledge and are interested in the topic can help to increase the content validity of Delphi and help increase the validity of the use of consecutive rounds of the survey (Hasson et. al., 2000). No reliability and validity studies were conducted for Delphi surveys because the number of respondents participating in the survey is very small. There is no opinion on sample size for Delphi researches, nor any suggestions or precise definitions of "small" or "large" examples. In literatures, 10 to 1685 participants were utilized in Delphi studies (Akins et. al., 2005). Reliability tests like cronbach alpha test cannot be applied with such low sample size. It is hard to say the minimum level of sample. Yurdugul (2008) referred a rich literature overview about minimum necessary sample size for cronbach alpha test. The minimum sample size for coefficient alpha is commonly recommended as 200, 300 or 500; he tried to give hints about the minimum sample size for Cronbach alpha test. Baskale (2016) mentioned that some researchers have emphasized that the number of samples for qualitative studies cannot be calculated, that the purpose of qualitative research is not to generalize the outcomes of the whole universe, and one or two cases are sufficient.

\subsection{Survey Design}

Survey questionnaire was designed by the dimensions and concepts that were derived from theoretical background/literature. The Delphi survey covered questions about topics like ;

- Quantitative valuation methods (namely reproduction method),

- $\quad$ Replacement Method, Sales Comparison Method,

- Comparable Profit Margin Method,

- Discounted Cash Flow Method,

- Incremental Income Method,

- Profit Split Method,

- Maximum Achievable Method,

- Technology Factor, Return on Investment Ratio,

- Relief from Royalty Method,

- Rules of Thumb,

- $5 \%$ of Sales Method,

- Profit Differential Method,

- Risk Adjusted NPV Method,

- Probability Tree Analysis,

- Monte Carlo Method and Real Option Pricing Method.

Total 15 experts participated to Delphi survey.

\begin{tabular}{|c|c|c|}
\hline Question & Scale & Source \\
\hline Personal Information & Nominal & $\mathrm{x}$ \\
\hline How much do you know about these methods? & Interval & $\mathrm{x}$ \\
\hline Have you ever used these methods to value an IP before? & Nominal & Expert in pre-survey interviews \\
\hline $\begin{array}{l}\text { When do you use these methods to value an IP, what is the } \\
\text { commercial or strategic purpose? }\end{array}$ & Nominal & $\begin{array}{l}\text { Lagrost et al., 2010, } \\
\text { Speier \& Gupta, } 2015\end{array}$ \\
\hline When/Why do you use this method? & Nominal & Speier \& Gupta, 2015 \\
\hline $\begin{array}{l}\text { What are the necessities or inputs of the application of this } \\
\text { method? }\end{array}$ & Nominal & Smith \& Parr, 2005, Hagelin, 2002 \\
\hline What are the difficulties in applying this method? & Nominal & Speier \& Gupta, 2015 \\
\hline What are the advantages of this method? & Nominal & Speier \& Gupta, 2015 \\
\hline Do you consider the qualitative approaches for future potential of & Nominal & Chiu and Chen (2007), Lagrost et al. \\
\hline
\end{tabular}


the technology being valued?

Do you apply more than one method to value an IP?

(2010)

Which methods do you use simultaneously to value an IP?

Nominal

Grube, 2009

After developing the survey that is presented in Table 5, a pilot study was conducted with some experts from UK and Turkey and the survey were organized in line with the recommendation of the expert before the survey was shared with targeted participants. In the end of pilot study, scales were edited; some new options were added to few questions, some typos and ambiguities were corrected.

\section{FINDINGS AND DISCUSSIONS}

\subsection{Awareness and Application Rate of IP Valuation Methods}

Second question and after were related with the valuation methods. According to responses regarding 18 valuation method taken from participants, rules of Thumb method is the most known technique at a rate of $73,3 \%$ and reproduction method is commonly used technique at a rate of $93,3 \%$. As can be seen in the Figure 4, all participants have information about rules of thumb, reproduction and DCF method. Replacement method, sales comparison and incremental income method are also among most well-known methods.

Figure 4: Level of Awareness About IP Valuation Methods

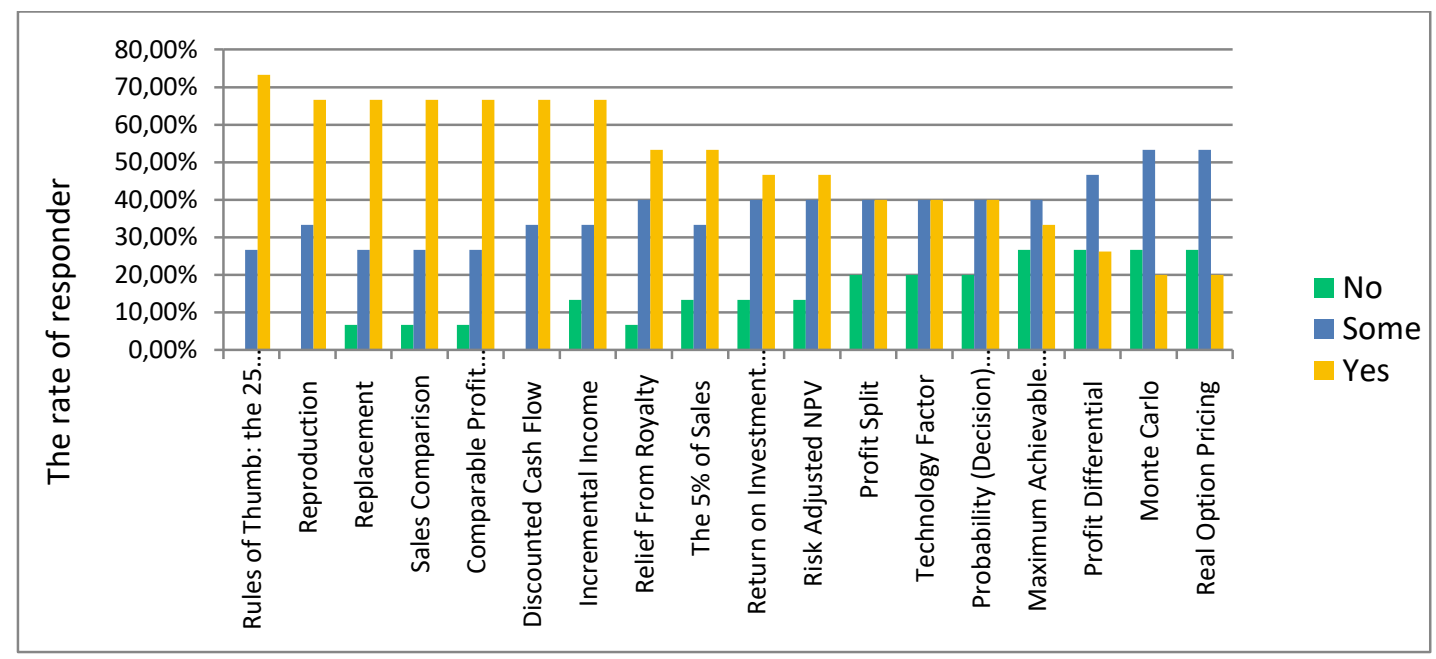

Figure 5: Application Rate of the IP Valuation Methods

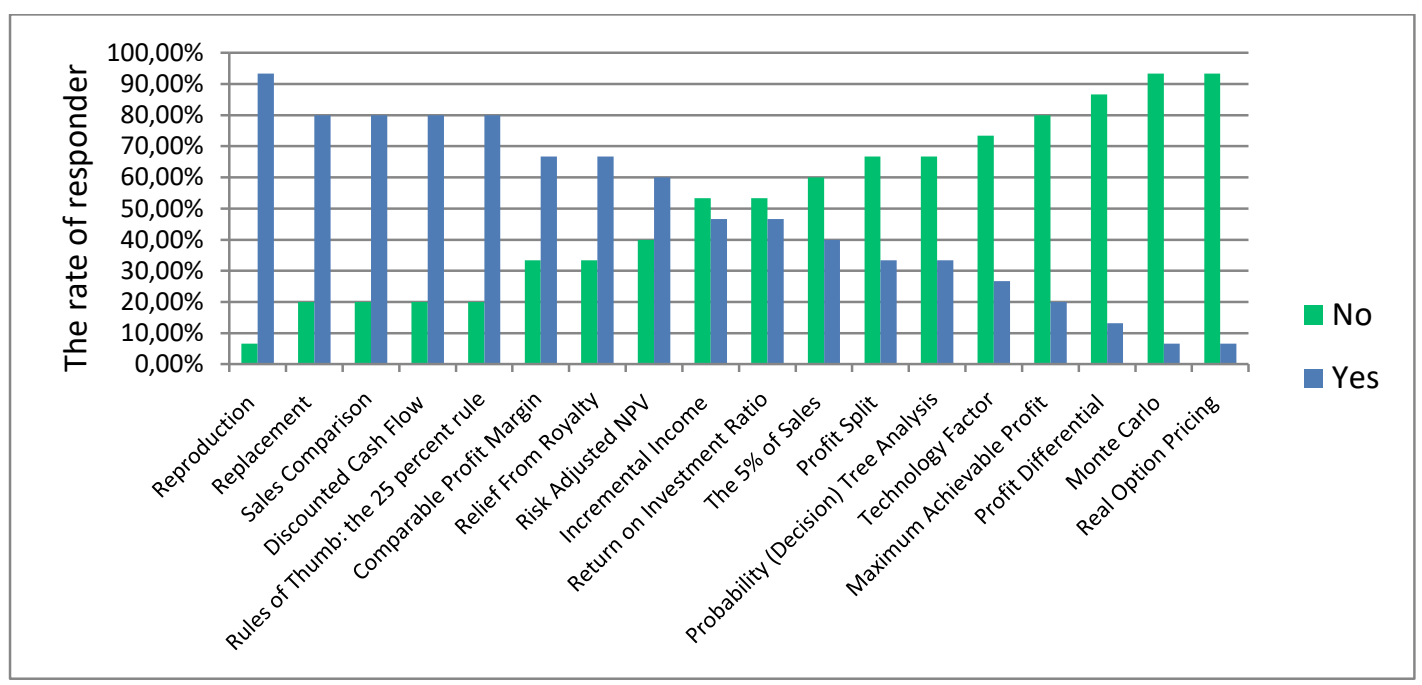

More than $60 \%$ of participants have used reproduction method, replacement method, sales comparison, discounted cash flow method, rules of thumb, comparable profit margin, relief from royalty method, risk adjusted NPV method before. 
When viewed from experiences and knowledge of participants, advanced valuation methods are known less than the other method and in parallel with this result they are not used by most participants. It can be seen in the Figure 4 and Figure 5 . Responses on the participants' know and/or used before and reply was not compulsory. Therefore, a different number of participants responded to each method.

\subsection{IP Valuation Methods by Purpose and Type}

Table 6 shows the purpose of using IP valuation methods and Table 7 show the data of when participants use these methods. The numbers in the tables represent the number of responder.

The first three most frequently chosen purpose for each method are Out-licensing, sale and portfolio analysis. The most preferred methods are also seen as DCF method, the $25 \%$ rule and replacement cost method. According to the opinion of respondents, cost based methods are less preferable for R\&D and merger \& acquisition purpose. In addition to R\&D and merger $\&$ acquisition purpose, in taxation issue comparing to other purposes, market based methods are less used. When the purposes for income method was examined, these methods are the least preferred in R \& D purpose. The purpose are not also R\&D and Tax advantage for advanced methods like market based method.

Table 6: IP valuation methods by Their Purpose of Usage

\begin{tabular}{|c|c|c|c|c|c|c|c|c|c|}
\hline Methods/ Answer Choices & $\begin{array}{l}\text { In- } \\
\text { licensing }\end{array}$ & $\begin{array}{l}\text { Out- } \\
\text { licensing }\end{array}$ & Sale & $\begin{array}{l}\text { R } \\
\& \\
D\end{array}$ & $\begin{array}{l}\text { Portfolio } \\
\text { Analysis }\end{array}$ & $\begin{array}{l}\text { Merger \& } \\
\text { Acquisition }\end{array}$ & Tax & Other & $\begin{array}{l}\text { Total } \\
\text { Preference }\end{array}$ \\
\hline Discounted Cash Flow & 4 & 7 & 7 & 1 & 8 & 3 & 2 & 2 & 34 \\
\hline Rules of Thumb: the $25 \%$ rule & 2 & 7 & 5 & 3 & 5 & 2 & 4 & 1 & 29 \\
\hline Replacement & 4 & 7 & 4 & 2 & 3 & 2 & 2 & 4 & 28 \\
\hline Sales Comparison & 2 & 9 & 5 & 1 & 6 & 1 & 0 & 0 & 24 \\
\hline Relief From Royalty & 2 & 5 & 5 & 1 & 3 & 2 & 3 & 2 & 23 \\
\hline Incremental Income & 2 & 5 & 4 & 2 & 3 & 2 & 2 & 2 & 22 \\
\hline Reproduction & 3 & 5 & 4 & 1 & 3 & 1 & 2 & 2 & 21 \\
\hline Profit Split & 3 & 5 & 5 & 1 & 2 & 1 & 1 & 2 & 20 \\
\hline Comparable Profit Margin & 2 & 6 & 3 & 1 & 4 & 0 & 2 & 1 & 19 \\
\hline Risk Adjusted NPV & 1 & 4 & 4 & 0 & 3 & 2 & 1 & 0 & 15 \\
\hline Probability/Decision Tree Analysis & 2 & 3 & 3 & 1 & 1 & 1 & 0 & 2 & 13 \\
\hline Return on Investment Ratio & 2 & 2 & 3 & 0 & 1 & 2 & 1 & 1 & 12 \\
\hline The $5 \%$ of Sales & 0 & 3 & 4 & 1 & 2 & 1 & 1 & 0 & 12 \\
\hline Technology Factor & 1 & 3 & 2 & 2 & 2 & 1 & 0 & 0 & 11 \\
\hline Profit Differential & 1 & 3 & 2 & 0 & 1 & 0 & 1 & 2 & 10 \\
\hline Maximum Achievable Profit & 1 & 2 & 2 & 0 & 1 & 0 & 0 & 0 & 6 \\
\hline Monte Carlo & 1 & 1 & 2 & 0 & 1 & 0 & 0 & 1 & 6 \\
\hline Real Option Pricing & 0 & 0 & 2 & 0 & 2 & 0 & 0 & 1 & 5 \\
\hline Total Preference & 33 & 77 & 66 & 17 & 51 & 21 & 22 & 23 & 310 \\
\hline
\end{tabular}

Table 6 shows the methods which are more applicable for which IP valuation purpose. While the real option pricing and the $5 \%$ of sales method was not chosen for in-licensing purpose, most of responder chose the replacement cost method and DCF method. For out-licensing purpose, most preferable method is sales comparison method and followings are replacement cost method, DCF method and rules of thumb method. DCF method is commonly used for valuation in sale, portfolio analysis and merger \& acquisition purpose. If the valuation need for R\&D and Tax advantage, Rules of Thumb $25 \%$ rule method is the most applicable method. According to opinion of some participant for "other" option, in case of investment in a patent, return on investment method can be used.

Table 7: The Method Applied in Different Usage

\begin{tabular}{|l|l|l|l|l|l|l|l|}
\hline Methods/ Answer Choices & $\begin{array}{l}\text { Early Stage } \\
\text { Technology } \\
\text { Valuation }\end{array}$ & $\begin{array}{l}\text { Business } \\
\text { Valuation }\end{array}$ & $\begin{array}{l}\text { In } \\
\text { Litigation } \\
\text { Situation }\end{array}$ & $\begin{array}{l}\text { Current } \\
\text { Portfolio } \\
\text { Analysis }\end{array}$ & $\begin{array}{l}\text { In sectors of } \\
\text { high } \\
\text { uncertainty } \\
\text { and risk }\end{array}$ & $\begin{array}{l}\text { Other } \\
\text { Total } \\
\text { Preference }\end{array}$ \\
\hline Rules of Thumb: the 25 \%rule & 10 & 4 & 3 & 6 & 7 & 3 & 31 \\
\hline Discounted Cash Flow & 7 & 8 & 3 & 6 & 3 & 1 \\
\hline Replacement & 9 & 4 & 5 & 3 & 28 & 2 \\
\hline Sales Comparison & 7 & 6 & 2 & 5 & 2 & 24 \\
\hline Relief From Royalty & 7 & 3 & 4 & 4 & 2 & 0 \\
\hline Comparable Profit Margin & 6 & 7 & 2 & 4 & 2 & 2 \\
\hline Reproduction & 9 & 3 & 3 & 3 & 22 & 2 \\
\hline
\end{tabular}




\begin{tabular}{|c|c|c|c|c|c|c|c|}
\hline Methods/ Answer Choices & $\begin{array}{l}\text { Early Stage } \\
\text { Technology } \\
\text { Valuation }\end{array}$ & $\begin{array}{l}\text { Business } \\
\text { Valuation }\end{array}$ & $\begin{array}{l}\text { In } \\
\text { Litigation } \\
\text { Situation }\end{array}$ & $\begin{array}{l}\text { Current } \\
\text { Portfolio } \\
\text { Analysis }\end{array}$ & $\begin{array}{l}\text { In sectors of } \\
\text { high } \\
\text { uncertainty } \\
\text { and risk }\end{array}$ & Other & $\begin{array}{l}\text { Total } \\
\text { Preference }\end{array}$ \\
\hline Incremental Income & 5 & 5 & 3 & 3 & 2 & 1 & 19 \\
\hline Profit Split & 4 & 3 & 3 & 5 & 2 & 2 & 19 \\
\hline Risk Adjusted NPV & 6 & 5 & 1 & 3 & 2 & 0 & 17 \\
\hline The $5 \%$ of Sales & 4 & 3 & 1 & 3 & 4 & 0 & 15 \\
\hline Probability (Decision) Tree Analysis & 5 & 3 & 1 & 1 & 3 & 0 & 13 \\
\hline Return on Investment Ratio & 2 & 3 & 0 & 1 & 2 & 0 & 8 \\
\hline Technology Factor & 2 & 2 & 0 & 2 & 1 & 0 & 7 \\
\hline Maximum Achievable Profit & 1 & 1 & 1 & 2 & 0 & 0 & 5 \\
\hline Profit Differential & 1 & 2 & 1 & 1 & 0 & 0 & 5 \\
\hline Monte Carlo & 2 & 2 & 0 & 0 & 1 & 0 & 5 \\
\hline Real Option Pricing & 2 & 1 & 0 & 1 & 1 & 0 & 5 \\
\hline Total Preference & 89 & 65 & 33 & 53 & 37 & 9 & 286 \\
\hline
\end{tabular}

As can be seen in Table 7, in various conditions (such as early stage technology valuation, business valuation, valuation in litigation situation, portfolio analysis or sectors under the high uncertainty and risk), different valuation methods can be used. The findings from responses of participants in the research revealed that $25 \%$ percent rule, reproduction cost method and replacement cost method are commonly used for early stage technology valuation. For business valuation, comparable profit margin and DCF method are mostly preferred. In litigation situation, an infringed IP right is valued in general by replacement cost and relief from royalty method. Besides that, technology factor, return on investment ratio, Monte Carlo and real option pricing method are never used according to the respondents. When current portfolio would be analyzed, DCF method, the 25 percent rule and sales comparison method are the mostly used methods. If the uncertainty and risk are high in a technology sector, the 25 percent rule and the sale of $5 \%$ is seen the most applied methods to value an IP in this sector. Similar to previous result in Table 6, for the general total of usage, the 25 percent rule method, DCF and replacement cost method distinguish from other methods.

\subsection{IP Valuation Methods by Their Necessities, Inputs, Challenges and Benefits}

When the necessities and inputs of application of the methods were asked to the participants, all methods except profit differential method, probability decision tree method, Monte Carlo method and real option pricing method were responded with minimum one necessity or input. The responses classified according to similar opinions. According to the responses taken from participants, requirements that are need to be known for the responded method are shown in Table 8.

Table 8: The Necessities and Inputs of Application of the Methods

\begin{tabular}{|l|l|}
\hline Methods & The Necessities/ Inputs \\
\hline Reproduction & Previous R \& D / Development Cost, Patent Cost \\
\hline Replacement & Previous R \& D/ Development Cost, Cost of replacing IP \\
\hline Sales Comparison & Market base data, Comparable Info/Deals, Adjustment for differences in deal factors \\
\hline Comparable Profit Margin & Market base data, Comparable Info/Deals \\
\hline Discounted Cash Flow & Discount Rate, Risk Factor, Future Income, Savings, Investment Cost, Time, Amount \\
\hline Incremental Income & Turnover of products with IP \\
\hline Profit Split & Turnover of products with IP \\
\hline Technology Factor & Need to know TRL \\
\hline Return on Investment Ratio & Risk factor, time, amount, making a good projection \\
\hline Relief From Royalty & $\begin{array}{l}\text { Market base data, Discount Rate, Risk Factor, Savings, Investment Cost, Amount, } \\
\text { Turnover of products with IP, Royalty Rate }\end{array}$ \\
\hline Rule of Thumb: the 25\%rule & Future Income, Profit Margin, Financials of products with IP \\
\hline Risk Adjusted NPV & Risk factor, Time, Amount \\
\hline
\end{tabular}

Responses regarding the difficulties in applying the methods and advantages of the methods had been various and did not present a significant frequency or consensus. However, some highlights come to the forefront as a difficulty or advantage. Early stage technology is seen as a challenge for using the comparable profit margin, DCF method, incremental income 
method and risk adjusted NPV method because these technologies have no income. Ease of application was indicated as an advantage of reproduction method, replacement method, the 25 percent rule and the $5 \%$ of sale method. Methods by their advantages and difficulties are presented in Table 9.

Table 9: IP Valuation Methods by Their Advantages and Difficulties

\begin{tabular}{|c|c|c|}
\hline Methods & Challenges/Difficulties & Advantages/ Benefits \\
\hline Reproduction & $\begin{array}{l}\text { - To determine the past cost (2) } \\
\text { - No relation to future income (1) } \\
\text { - Past cost may be high if costumer needs are } \\
\text { not satisfied (1) } \\
\text { - Lack of data and information (1) } \\
\text { - ignoring the unique or novel characteristics } \\
\text { of IP (1) }\end{array}$ & $\begin{array}{l}\text { - Suitable for early stage technologies (2) } \\
\text { - Suitable if there is no direct cash flow being } \\
\text { generated from use of the subject IP assets (1) } \\
\text { - Costs are defined in the projects (1) } \\
\text { - Easy to apply/calculate (1) }\end{array}$ \\
\hline Replacement & $\begin{array}{l}\text { - Past cost may be high if costumer needs do } \\
\text { not be satisfied (1) } \\
\text { - To find comparable IP/ market case (1) } \\
\text { - Ignoring risk factor and uncertainty (1) }\end{array}$ & $\begin{array}{l}\text { - Suitable for early stage technologies (2) } \\
\text { - Suitable if there is no direct cash flow } \\
\text { generated from IP assets (1) } \\
\text { - Costs are defined in the projects (1) } \\
\text { - Easy to apply/calculate (1) } \\
\text { - No need business plan (1) }\end{array}$ \\
\hline $\begin{array}{l}\text { Sales } \\
\text { Comparison }\end{array}$ & $\begin{array}{l}\text { - To find comparable IP/ market case (3) } \\
\text { - Regions (3) }\end{array}$ & $\begin{array}{l}\text { - Very useful good indicator if exact comparable } \\
\text { are available (2) } \\
\text { - Seeing the real numbers (1) }\end{array}$ \\
\hline $\begin{array}{l}\text { Comparable } \\
\text { Profit Margin }\end{array}$ & $\begin{array}{l}\text { - To find comparable IP/ market case (1) } \\
\text { - Early stage technologies have no income (1) }\end{array}$ & $\begin{array}{l}\text { - Very useful and good indicator if exact } \\
\text { comparable are available (1) } \\
\text { - You value others (1) }\end{array}$ \\
\hline $\begin{array}{l}\text { Discounted } \\
\text { Cash Flow }\end{array}$ & $\begin{array}{l}\text { - Early stage technologies have no income (1) } \\
\text { - To predict the future for early stage } \\
\text { technology and others (2) } \\
\text { - To discount uncertainties (1) }\end{array}$ & $\begin{array}{l}\text { - valuation is comparable to other investment } \\
\text { decisions, discounting and time value of } \\
\text { money is standard in other valuations (1) } \\
\text { - good to determine the influence of risk and } \\
\text { time and to get numbers for selling the } \\
\text { technology (1) } \\
\text { - easiest way to use cash flows are currently } \\
\text { positive and can be forecasted with some } \\
\text { reliability (1) }\end{array}$ \\
\hline $\begin{array}{l}\text { Incremental } \\
\text { Income }\end{array}$ & - Early stage technologies have no income (1) & 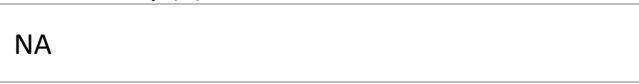 \\
\hline $\begin{array}{l}\text { Technology } \\
\text { Factor }\end{array}$ & $\begin{array}{l}\text { - To have good knowledge about the } \\
\text { technology (1) }\end{array}$ & $\begin{array}{l}\text { - automatically compare with the technology } \\
\text { level (1) }\end{array}$ \\
\hline $\begin{array}{l}\text { Relief From } \\
\text { Royalty }\end{array}$ & $\begin{array}{l}\text { - To predict the future for early stage } \\
\text { technology d others (1) } \\
\text { - Assumptions on potential licenses (1) }\end{array}$ & NA \\
\hline $\begin{array}{l}\text { Rules of } \\
\text { Thumb: the } \\
25 \% \text { rule }\end{array}$ & $\begin{array}{l}\text { - profit based methods can be manipulated } \\
\text { (attributable costs) (1) } \\
\text { - to determine calculation base (\% profit } \\
\text { based on invention) (1) }\end{array}$ & $\begin{array}{l}\text { - easy to apply/calculate (1) } \\
\text { - Need less time and effort than other } \\
\text { methods(1) }\end{array}$ \\
\hline $\begin{array}{l}\text { The } 5 \% \text { of } \\
\text { Sales }\end{array}$ & NA & - Easy to apply/calculate (2) \\
\hline $\begin{array}{l}\text { Risk Adjusted } \\
\text { NPV }\end{array}$ & $\begin{array}{l}\text { - Early stage technologies have no income } \\
\text { (1) } \\
\text { - To assess the risk reliably (1) }\end{array}$ & NA \\
\hline $\begin{array}{l}\text { Real option } \\
\text { pricing }\end{array}$ & 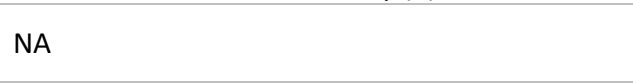 & - $\quad$ More than one scenario considered (1) \\
\hline
\end{tabular}

The numbers in parentheses represent the number of respondents. 
Separately from the question regarding the quantitative methods, considering qualitative methods, its effect to the value of technology and the steps they used the qualitative indicators were asked to the participant. 14 participants responded this question. $86 \%$ of respondents given answer as "yes" and $14 \%$ of the respondents given and answer as "no". Some respondents have similar opinion about the effect and phase of considering qualitative methods. They think that the qualitative approach is useful for assessing the IP. One responder indicate that he/she use the qualitative approach throughout the valuation.

Some other comments of experts about the usefulness are summarized below:

"Qualitative factors are used to assess the strategic importance and key questions regarding the technology, marketing etc. The goal of this is to get a holistic picture and explore alternative scenarios etc. not just relying on simple financial assumptions."

"to evaluate an overall supremacy of the IP you need qualitative indicators as well."

"For each method used for valuation, the respective parameters are selected based on the qualitative assessment of the technology."

$93 \%$ of respondents of all indicated that they apply more than one method to value an IP. Their opinions were received on which methods they applied together. Depending on objectives and situation was remarked by 5 respondents. Besides, the different combinations of the methods were suggested by the respondents. These suggestions are listed in below:

- NPV and Qualitative Methods

- DCF and Market Method

- Reproduction, Market, RFR, 25\% Rules

- Cost Methods and Market Methods

- Reproduction and Replacement Method

- DCF and another one

- Rule of Thumb, Replacement Method, Sales Comparison Method

- Technology Factor, Sales Comparison and Replacement

- Replacement, Reproduction, Sales Comparison, Comparable Profit Margin, DCF

- At least two approaches from the methods such as Reproduction, Replacement, Sales Comparison, the 25 percent rule, the $5 \%$ of Sales, DCF, return on Investment Ratio, Probability Tree Analysis

The findings of this study show the whole necessities/inputs to apply valuation method in line with the literature. According to the literature, cost methods are known as easily applicable methods. The Delphi survey results show that the $5 \%$ of sale method and Rules of Thumb: $25 \%$ percent rule method are perceived as easy to apply in addition to cost methods. On the other hand, the application comparable profit margin method, DCF method, Incremental Income method and risk adjusted NPV methods are thought not to be easy.

While a parameter is indicated as advantage for applying a method according to one opinion, it is seen that the same parameter can cause difficulties for applying same method for others. This situation can be explained with the lack of data needed to apply the method. If the information which is fundamental for applying the valuation method is accessible, this information can be indicated as a benefit for valuation process.

\section{CONCLUSION}

Findings reveal that replacement cost, reproduction cost, sales comparison, DCF, the 25 percent rule, comparable profit margin and RFR methods are widely preferred and known IP valuation methods which are priorly expressed by the respondent experts of this study. Advanced valuation methods are much rarely known and used when compared to previously stated methods. On the other hand, the findings of some other questions regarding purpose of valuation method and different situations of IP valuation and sectors inform about the preference of all IP valuation method indirectly. Replacement cost method, DCF method, the 25 percent rule and RFR method are also found as commonly used or known methods.

Sales comparison method have occurred as the mostly agreed suitable method for licensing purpose. Replacement cost method, DCF methods, Rules of Thumb: 25 percent rule are also seen as more suitable than the other methods for licensing purpose. For IP sale, DCF method is found to be the most appropriate method. IP valuation is made least for merger \& 
acquisition (M\&A) and R\&D purpose. Sales comparison method, profit split method, the 25 percent rule and DCF method are shown as mostly used for purpose of IP portfolio analysis. In taxation issue, the Rules of Thumb: 25 percent rule method and RFR method are more suitable for IP valuation. The results regarding the valuation purpose are aligned with the previous literature, in general.

Cost methods, DCF method, the 25 percent rule, sales comparison method and RFR method were indicated as suitable for early stage technologies. The 25 percent rule, sales comparison method and RFR method were revealed among the appropriate methods for early stage in our new findings. Mostly used methods in litigation situation are replacement cost method and RFR method. Market methods and DCF method are mostly used for business valuation. For other usage area of the methods are in line with the study of Lagrost et al. (2010).

Also study findings revealed that when an IP is valued, qualitative parameters should be considered because of their indirect affect to the valuation. It is a necessity to evaluate the overall picture and to determine some required parameters for valuation. In order to make effective and well-supported estimates of an IP value, more than one valuation method which can be selected according to the objectives and different situations and qualitative parameters should be considered because of their indirect effect to the valuation. DCF method is stated in most of suggested different valuation method groups.

The characteristics and comparison of all valuation methods, opinion based on experiences of the IP valuation experts and the findings of Delphi survey that are presented in this study are expected to help valuers that are in need of choosing most suitable valuation method for their IPs. In spite of the fact that some findings could not reach a consensus, this study allows experts to determine a road map for IP valuation process.

Limitations and Further Research : There are not many practices and experts about IP valuation in Turkey. Also limited available studies. IP valuation experts are not available via some channels like patent attorney, PMP or RTTP. Panel since Delphi group have been selected from different countries and any funding for a meeting were not available for our research. Thirdly and most challenging there was not a comparative study about all methods that were presented in this study. For discussing the findings, a comparable study could not be found for each response or method. For example, one of the most cited articles in the field is the one that belongs to Lagrost et al. (2010) and it is as well conceptual paper. On the other hand, Wang (2016) is a similar study to ours and it includes sampling of five TTO in Taiwan for data collection while in our studied we collected data from 15 experts from different institutions hence we can easily underline that our research methodology is a step forward to provide perspective, deeper insight for own IP valuation study.

\section{Acknowledgements}

This article is derived from the Master of Science thesis of Aysun Beyazkllıç Koç which is submitted to Istanbul Technical University Science and Technology Institute Management Engineering Programme in May 2018 and supported by Scientific Research Unit (BAP) of ITU.

\section{REFERENCES}

Akins, R. B., Tolson, H., Cole, B. R. (2005). Stability of response characteristics of a Delphi panel: application of bootstrap data expansion. $B M C$ medical research methodology, 5(1), 37.

Andriessen, D. (2004). Making sense of intellectual capital: designing a method for the valuation of intangibles. Routledge.

Anson, W., Suchy, D. (2005). Intellectual property valuations. a primer for identifying and determing value. Chicago Google Scholar.

Anson, W., Noble, D., Samala, J. (2014). IP valuation: what methods are used to value intellectual property and intangible assets. The Licensing Journal, 34(2), 1-5.

Başkale, H. (2016). Nitel araştırmalarda geçerlik, güvenirlik ve örneklem büyüklüğünün belirlenmesi. Dokuz Eylül Üniversitesi Hemşirelik Fakültesi Elektronik Dergisi, 9(1).

Brancheau, J. C., Janz, B. D., Wetherbe, J. C. (1996). Key issues in information systems management: 1994-95 SIM Delphi results. MIS quarterly, 225-242.

Carte, N. (2005). The maximum achievable profit method of patent valuation. International Journal of Innovation and Technology Management, 2(02), 135-151.

Cetin, M. (2017). Sınai mülkiyet haklarinda kurumlar vergisi ve KDV istisnası. Retrieved December 27, 2017, http://www.verginet.net/dtt/1/sinai-mulkiyet-haklarinda-KV-KDV-istisnasi.aspx

Çetindamar, D., Phaal, R., Probert, D. (2010). Technology management activities and tools. Palgrave-Macmillan.

Chiu, Y. J., Chen, Y. W. (2007). Using AHP in patent valuation. Mathematical and Computer Modelling, 46(7-8), 1054-1062. 
Cohen, J. A. (2011). Wiley finance: intangible assets: valuation and economic benefit. Hoboken, Wiley, USA.

Cromley, J. T. (2004). 20 steps for pricing a patent. Journal of Accountancy, 198(5), 31.

Culley, J. M. (2011). Use of a computer-mediated Delphi process to validate a mass casualty conceptual model. Computers, informatics, nursing: CIN, 29(5), 272.

Dalkey, N., Helmer, O. (1963). An experimental application of the Delphi method to the use of experts. Management science, 9(3),458-467.

Dubiansky, J. E. (2006). An analysis for the valuation of venture capital-funded startup firm patents. BUJ Sci. \& Tech. L., 12, 170.

European Commission. (2013). Final report from the expert group on IP valuation. Luxemburg: Publication Office of EU.

Ferguson, S. M. (2016). Technology commercialization transition from science to business. Published presentation of National Workshop on Innovation Promotion and Technology Transfer. Istanbul: September 6

Flignor, P., Orozco, D. (2006). Intangible asset \& intellectual property valuation: a multidisciplinary perspective. ipthought. com.

Goddar M., Moser U. (2011). Traditional valuation methods: cost, market and income approach. In F. Munari, R. Oriani (Eds.), The Economic Valuation of Patents (1nd ed., pp.109-134). Massachusetts : Edward Algar.

Griliches, Z. (1998). Patent statistics as economic indicators: a survey. In R\&D and productivity: the econometric evidence (p. 310). University of Chicago Press.

Grube, C. (2009). Measuring the immeasurable valuing patent protection of knowledge-based competitive advantages (p. 154). Gabler.

Guest, G., Namey, E., Taylor, J., Eley, N., McKenna, K. (2017). Comparing focus groups and individual interviews: findings from a randomized study. International Journal of Social Research Methodology, 20(6), 693-708.

Hadzima, G. J. (2013). How to tell what patents are worth. Retrieved February 12, 2017, retrived from https://www.forbes.com/sites/forbesleadershipforum/2013/06/25/how-to-tell-what-patents-are-worth/\#6fa20b7c6e5b

Hagelin, J. C. (2002). The kinds of traits involved in male-male competition: a comparison of plumage, behavior, and body size in quail. Behavioral Ecology, 13(1), 32-41.

Hamamcioglu V., Kahraman D. (2015, November). Patent degerleme. AIPPI Türkiye. Retrieved from https://www.aippiturkey.org/aippiturkiye-bulteni-sayi-9/

Harhoff, D., Scherer, F. M., Vopel, K. (2003). Citations, family size, opposition and the value of patent rights. Research policy, 32(8), 13431363.

Hasson, F., Keeney, S., McKenna, H. (2000). Research guidelines for the Delphi survey technique. Journal of advanced nursing, 32(4), 10081015.

Hayne, S. C., Pollard, C. E. (2000). A comparative analysis of critical issues facing Canadian information systems personnel: a national and global perspective. Information \& Management, 38(2), 73-86.

Holt, K. F., O'Shaughnessy, B. P., Herman, T. B. (2005). What's it worth?: principles of patent valuation.

Kranakis, E. (2007). Patents and power: European patent-system integration in the context of globalization. Technology and Culture, 48(4), 689-728.

Lagrost, C., Martin, D., Dubois, C., Quazzotti, S. (2010). Intellectual property valuation: how to approach the selection of an appropriate valuation method. Journal of Intellectual Capital, 11(4), 481-503.

Lanjouw, J., Schankerman, M. (2003). Enforcement of patent rights in the United States (pp. 143-179). Washington, DC: The National Academies Press.

Marr, B., Gray, D., Neely, A. (2003). Why do firms measure their intellectual capital?. Journal of intellectual capital, 4(4), 441-464.

Murphy, J. W., Orcutt, J. L., Remus, P. C. (2012). Patent valuation improvng decision making through analysis (1nd ed., pp. 5- 253). New Jersey: Wiley.

Narin, F., Noma, E., Perry, R. (1987). Patents as indicators of corporate technological strength. Research policy, 16(2-4), $143-155$.

Okoli, C., Pawlowski, S. D. (2004). The Delphi method as a research tool: an example, design considerations and applications. Information \& management, 42(1), 15-29.

Oriani R., Sereno L. (2011). Advanced valuation methods: the real options approach. In F. Munari, R. Oriani (Eds.), The Economic Valuation of Patents (1nd ed., pp.142-152). Massachusetts: Edward Algar.

Parr, R. L. (2016). Royalty Rates for Medical Devices \& Diagnostics. IPRA, Inc.

Parr, R. L., Smith, G. V. (2005). Intellectual property: valuation, exploitation, and infringement damages. John Wiley \& Sons. 
Pitkethly, R. (1997). The valuation of patents: a review of patent valuation methods with consideration of option based methods and the potential for further research.Research Papers in Management Studies/University of Cambridge Judge Institute of Management Studies

Putnam, J. D. (1997). The value of international patent rights.

Reilly, R. F. (2016). The market approach to valuing intangible assets. Retrieved from http://www.willamette.com/pubs/presentations3/reilly_valuation_strategies_may_june_2016.pdf

Reilly, R. F., Schweihs, R. P. (1999). Valuing intangible assets. McGraw Hill Professional.

RICS. (2015). Valuation of intellectual property rights. RICS guidance note, global 1st edition, May 2015, UK.

Singh, S., Paliwal, M. (2014). Exploring a sense of IP valuation for Indian SMEs. Int. J. Asian Bus. Inf. Manag. 5, 1, 15-36.

Smith, G. V., Parr, R. L. (2000). Valuation of intellectual property and intangible assets (Vol. 13, p.152). Wiley.

Sozer, M. N. (2008). Patent değerlemesi ve Türkiye'deki uygulamaları. Retrieved July 27, 2016, from http://www.teknolojitransferi.gov.tr/TeknolojiTransferPlatformu/resources/temp/DD8383E4-1C84-47CD-B54C1D4673691B43.pdf;jsessionid=1F2DE15090256CDB3EE9427818C425C3

Speier, G. J., Gupta, R. (2015). Intellectual property valuation: asset strength approach (Evaluation of the Strength of an Asset Against the Commercial Technology Covered by the Asset).

Stevens, A. J. (2016). Intellectual property valuation manual for academic institutions (Report No. CDIP/17/INF/4). Geneva: Committee on Development and Intellectual Property (CDIP).

Taplin, R. (Ed.). (2004). Valuing intellectual property in Japan, Britain and the United States. Routledge.

The Canadian Institute of Charted Business Valuators (2011). OECD TP WP6: illustrative example of intangible asset valuation. Retrieved from http://www.oecd.org/tax/transfer-pricing/47426115.pdf

Trajtenberg, M. (1990). A penny for your quotes: patent citations and the value of innovations. The Rand Journal of Economics, $172-187$

Van der Drift, J. (1988). Statistics of European patents on legal status and granting data. World Patent Information, 10(4), $243-249$.

Wang, M. Y. (2016, September). The valuation methods and applications for academic technologies in Taiwan. In Management of Engineering and Technology (PICMET), 2016 Portland International Conference on (pp. 1320-1327). IEEE.

World Intellectual Property Organization. (2012). National Workshop on Innovation Promotion and Technology Transfer: Ankara: Introduction to the Basic IP Valuation Issues [PowerPoint slides]. Retrieved from

The General Communiqué on the Amendment of the Corporate Tax. (2014) Official Gazette, 28918, 19 February 2014

Turkish Law of Intellectual Property Rights numbered 6769. (2016). Official Gazette, 29944, 10 January 2017

Turkish Secondary Law of Intellectual Property Rights numbered 551. (1995). Official Gazette, 22326, 27 June 1995

Url-1 <http://www.turkpatent.gov.tr/TURKPATENT/statistics/>, date retrieved 17.01.2018.

Url-2 <http://www.wipo.int/treaties/en/text.jsp?file_id=283698\#P127_22000>, date retrieved 20.07.2017.

Url-3<(https://www.tubitak.gov.tr/tr/destekler/akademik/ulusal-destek-programlari/icerik-1513-teknoloji-transfer-ofisleri-desteklemeprogrami)>, date retrieved 08.01.2018. 